DIW BERLIN

Discussion

Papers
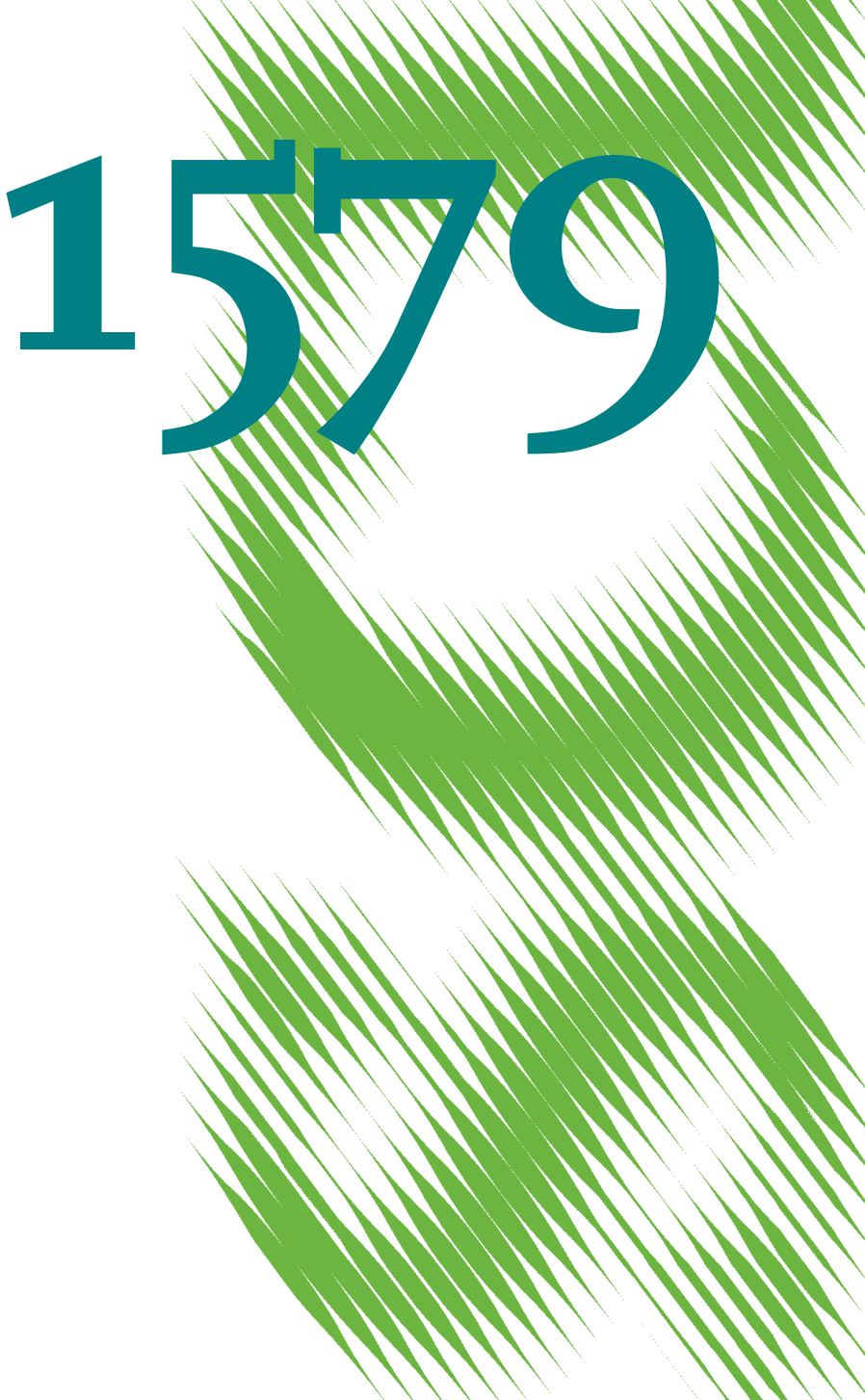

Inclusion of Consumption into Emissions Trading Systems: Legal Design and Practical Administration 
Opinions expressed in this paper are those of the author(s) and do not necessarily reflect views of the institute.

IMPRESSUM

(C) DIW Berlin, 2016

DIW Berlin

German Institute for Economic Research

Mohrenstr. 58

10117 Berlin

Tel. +49 (30) $89789-0$

Fax +49 (30) $89789-200$

http://www.diw.de

ISSN electronic edition 1619-4535

Papers can be downloaded free of charge from the DIW Berlin website:

http://www.diw.de/discussionpapers

Discussion Papers of DIW Berlin are indexed in RePEc and SSRN:

http://ideas.repec.org/s/diw/diwwpp.html

http://www.ssrn.com/link/DIW-Berlin-German-Inst-Econ-Res.html 


\title{
Inclusion of Consumption into Emissions Trading Systems: Legal Design and Practical Administration
}

\author{
Roland Ismer ${ }^{1}$, Manuel Haussner ${ }^{2}$, Karsten Neuhoff ${ }^{3}$, William Acworth ${ }^{4,5}$
}

\begin{abstract}
A world of unequal carbon prices requires measures aimed at preventing carbon leakage. Climate policy imperatives demand that such measures must be compatible with the goal of sending a carbon price signal down the value chain. For carbon intensive materials, the combination of dynamic free allocation combined with Inclusion of Consumption (IoC) into emissions trading systems such as the European Union Emissions Trading Scheme (EU ETS) arguably fulfils both the aims of preventing carbon leakage and of sending the price signal. The paper presents concrete proposals regarding the legal design and practical administration of this mechanism. It argues that the IoC is, provided appropriate choices are made, ripe for implementation.
\end{abstract}

Keywords: Carbon Pricing, value chain, consumption charge

JEL: H23, K23, L61

\footnotetext{
1 Prof. Roland Ismer holds the Chair for Tax Law and Public Law at the Friedrich-Alexander-University Erlangen-Nuremberg (FAU) and is a Research Fellow at the German Institute for Economic Research (DIW Berlin).

${ }^{2}$ Manuel Haussner is a research assistant and doctoral candidate at the Chair for Tax Law and Public Law at the FAU.

${ }^{3}$ Prof. Karsten Neuhoff holds the Chair of Energy and Climate Policy at the Technical University of Berlin and is Head of Department of Climate Policy at the German Institute for Economic Research (DIW Berlin).

${ }^{4}$ William Acworth is Project Manager at the International Carbon Action Partnership (ICAP), william.acworth@icapcarbonaction.com.

${ }^{5}$ The authors wish to thank Jan Stede, Michael Tervooren, Ruud Tusveld, Vera Zipperer as well as participants at workshops in Berlin and Brussels.
} 


\section{A. Introduction}

Mitigation of climate change requires a deep decarbonisation of the whole economy. ${ }^{6}$ Given that materials production is responsible for a major share of emissions, ${ }^{7}$ a very important contribution has to come from these sectors. This means that improvements need to be induced on three levels: ${ }^{8}$ (i) efficiency enhancement of production and a shift towards lowercarbon fuel types; (ii) innovation and deployment of break-through technologies for lower carbon production like Carbon Capture and Storage (CCS) as well as Carbon Capture and Use (CCU); and (iii) more efficient materials usage, including a move to higher quality materials and substitution towards innovative and less-carbon intensive materials.

In a world of equal carbon prices, the EU Emissions Trading Scheme (EU ETS) would promote all three mitigation options. Carbon pricing delivers incentives to producers to enhance production efficiency. ${ }^{9}$ Sending a price signal along the value chain by passing on carbon costs onto consumption prices engages consumers in emissions reductions through substitution and innovation. ${ }^{10}$ A clear allocation of carbon costs creates clarity on the allocation of incremental costs of carbon reduction, and provides incentives for long-term investment in breakthrough technologies. ${ }^{11}$

Yet as emphasis on the carbon price in the policy mix and the level of ambition in mitigation effort may differ between countries, ${ }^{12}$ carbon prices are expected to vary across

\footnotetext{
${ }^{6}$ The European Union has set itself an emissions reduction target of $80-95 \%$ for 2050 , cf. Council of the European Union, 'Brussels European Council - 29/30 October 2009 - Presidency Conclusion', 15265/09 CONCL 3, at para 7.

${ }^{7}$ The iron and steel, and the cement sectors alone account for around 40 per cent of industrial emissions in the European Union, see S.M. de Bruyn et al., Ex-post investigation of cost pass-through in the EU ETS - An analysis for six sectors (Publications Office of the European Union 2015), at p 25.

${ }^{8} \mathrm{~K}$. Neuhoff et al., Inclusion of Consumption of carbon intensive materials in emissions trading - An option for carbon pricing post-2020 (Climate Strategies Report, May 2016). Cement sector specific emission reductions potentials are provided in industry roadmaps: see e.g. Cembureau, The role of cement in the 2050 low carbon economy (Cembureau 2013), at pp 26 to 57; Mineral Products Association, MPA Cement GHG Reduction Strategy (Mineral Products Association 2013); A. Pineda et al., Sectoral Decarbonization Approach (SAD): A method for setting corporate emission reduction targets in line with climate science (Science Based Targets Initiative 2015). For the steel sector see the policy summary by K. Neuhoff et. al., Carbon Control and Competitiveness Post 2020: The Steel Report - Final Report (Climate Strategies 2014), at pp 14 to 45.

${ }^{9}$ See T.H. Tietenberg, Emissions Trading - Principles and Practice (2nd edn, Resources for the Future and RFF Press book 2006, at pp 27 et seqq; M. Grubb et al., Planetary Economics (Routledge 2014), chapter 6 on pricing pollution and chapter 7 on cap-and-trade and offsets.

${ }^{10}$ For the case of the EU ETS see Case C-566/11 Iberdrola, SA and Others $v$ Administración del Estado EU:C:2013:660, Opinion of Advocate General (AG) Kokott, at paras 70 et seq. AG Kokott stated on the passing of carbon costs onto electricity consumption prices: "If the opportunity costs of the allowances are integrated into consumer prices, that price signal gives consumers an additional incentive to consume less electricity and thus to help to reduce greenhouse gas emissions. Although Directive 2003/87 does not expressly mention this incentive for final consumers, it is consistent with the logic of the market mechanism created by it. That mechanism is intended to put a price on environmental pollution so that those costs are included in the decisionmaking of all relevant actors". See also Commission, 'Green Paper on Greenhouse Gas Emissions Trading within the European Union’ COM(2000) 87 final, at para 7.3; R. Ismer, Klimaschutz als Rechtsproblem (Mohr Siebeck 2014), at p 104.

${ }^{11}$ M. Grubb et al., n. 9 above, chapter 6.2 on why price matters; M. Grubb et al., Analyses of the effectiveness of trading in EU-ETS' (Climate Strategies 2012), at p 22.

${ }^{12}$ An overview of current and planned carbon pricing schemes is provided by A. Kossoy, State and Trends of Carbon pricing (World Bank 2015).
} 
regions in the long term. This raises concerns about so-called carbon leakage ${ }^{13}-\mathrm{a}$ shift of emissions through a relocation of the production of carbon-intensive commodities to regions with lower carbon prices. As a result of carbon leakage, the carbon price signal is muted ${ }^{14}$ along the value chain and incentives for innovation, substitution and material efficiencies are lost.

Free allocation, which is the mechanism presently implemented in the EU ETS in order to address carbon leakage, ${ }^{15}$ does not restore these incentives: under free allocation, sectors and subsectors exposed to risk of carbon leakage receive free allowances. While this reduces the competitive advantage of production outside the territorial borders of the emissions trading system and thus addresses carbon leakage concerns, ${ }^{16}$ it does so by decreasing the effective (marginal) carbon price for goods from these sectors. Free allocation thus fails to transmit an effective carbon price along the value chain, which would be necessary for substitution, innovation and efficient use of materials. ${ }^{17}$

The literature has therefore examined alternative approaches to address carbon leakage. ${ }^{18}$ Most attention has been devoted to Border Carbon Adjustments (BCA). ${ }^{19}$ Under

\footnotetext{
${ }^{13}$ See F. Sindico, 'The EU and Carbon Leakage: How to Reconcile Border Adjustments with the WTO?', 17:6 European Energy and Environmental Law Review (2008), at p 328; S. Dröge et al., Tackling Leakage in a World of Unequal Carbon Prices (Climate Strategies 2009); S. Monjon and P. Quirion, 'How to Design a Border Adjustment for the European Union Emissions Trading System?', 38:9 Energy Policy (2010), 5199, at pp 5200 et seq; T. Tietenberg, 'Reflections - Carbon Pricing in Practice' 7:2 Review of Environmental Economics and Policy (2013), 313, at p 319; A. Marcu et al., 'Carbon leakage: Options for the EU' (CEPS Carbon Market Forum 2014), Annex 1 - Background on Carbon Leakage.

${ }^{14}$ Besides carbon costs, the ability to pass on carbon costs is another factor that needs to be taken into account. Where there is no such a possibility, the risk of carbon leakage increases (A. Marcu et al., n. 13 above, at p 2). Marcu et al., further noted that the ability to pass on carbon costs is more difficult to quantify, as a pass on of carbon costs is also determined by industry-specific and economy wide characteristics (ibid, at pp 3 et seq.).

${ }^{15}$ See Art. 10a of Directive 2003/87/EC of the European Parliament and of the Council of 13 October 2003 establishing a scheme for greenhouse gas emission allowance trading within the Community and amending Council Directive 96/61/EC [2003] OJ L 275, 1 as amended by Directive 2009/29/EC of the European Parliament and of the Council of 23 April 2009 amending Directive 2003/87/EC so as to improve and extend the greenhouse gas emission allowance trading scheme of the Community [2009] OJ L 140, 63. Currently, free allocation is based on historic activity data and an emissions intensity benchmark, see Commission Decision 2011/278/EU of 27 April 2011 determining transitional Union-wide rules for harmonised free allocation of emission allowances pursuant to Article 10a of Directive 2003/87/EC of the European Parliament and of the Council [2011] OJ L130, 1. For an overview of different allocation methods see S. Dröge et al., n. 13 above, at pp 46-54. A comparison between allocation bases on historic reference base and current output is provided by P. Quirion, 'Historic Versus Output-based Allocation of GHG Tradable Allowances: A Comparison', 9:6 Climate Policy (2007), 575.

${ }^{16}$ See S. Dröge et al., n. 13 above, at pp 46 et seqq.

${ }^{17}$ On cost-pass-through rates see Commission, n. 7 above. On the economic drawbacks of free allocation see e.g. C. Hepburn et al., 'Auctioning of EU ETS Phase II Allowances. How and Why?, 6:2 Climate Policy (2006), 137, at p 140; L. Clarke et al., 'International Climate Policy Architectures: Overview of the EMF 22 International Scenarios', 31:2 Energy Economics (2009), 264, at pp 264 et seqq; R. Heilmayr and J. Bradbury, 'Effective, efficient or equitable: using allowance allocation to mitigate emissions leakage', 11:4 Climate Policy (2011), 1113, at p 1114; K. Neuhoff and A. Schopp, Europäischer Emissionshandel: Durch Backloading Zeit für Strukturreform gewinnen (DIW 2013), at pp 4 et seqq; B. Borkent et al., Dynamic Allocation for the EU Emissions Trading System: Enabling Sustainable Growth (Ecofys 2014), at p 1; R. Ismer, n. 10 above, at p 172 and p 179; P. Quirion, n. 15 above, at pp 581 et seqq; F. Branger et al., EU ETS, Free Allocations and Activity Level Thresholds: The Devil Lies in the Details (Centre for Climate Change Economics and Policy and Grantham Research Institute on Climate Change and the Environment 2014).

${ }^{18}$ Cf. e.g. J. Stiglitz, 'A new agenda for global warming', 3:7 The Economists' Voice' (2006); J. Bhagwati, 'Is action against US exports for failure to sign Kyoto Protocol WTO-Legal?’, 6:2 World Trade Review (2007), 229;
} 
this approach, all domestic producers would have to acquire allowances either through auctions or at the carbon market. A charge would then be imposed on imports according to their carbon content to level the playing field. Exports in contrast would receive rebates for the costs incurred due to carbon pricing. ${ }^{20}$ Domestic producers would now be able to pass on carbon costs onto consumption prices without risking a loss in competitiveness. Accordingly, BCA would deliver a carbon price along the value chain. Although economically sound, ${ }^{21}$ BCA have not been implemented thus far due to political constraints and insecurity regarding their compatibility with WTO Law. ${ }^{22}$

Recently, a new policy mechanism in the form of a charge on the consumption of carbon intensive commodities has been suggested to re-establish the full emissions reduction

C. Fischer and A. Fox, Comparing policies to combat emissions leakage: border adjustments versus rebates (RFF Discussion Paper, Resources for the Future 2009).

${ }^{19}$ See, e.g., H. van Asselt and F. Biermann, 'European Emissions Trading and the International Competiveness of Energy-intensive Industries: A Legal and Political Evaluation of Possible Supporting Measures', 35:1 Energy Policy (2007), 497, at p 502; R. Ismer and K. Neuhoff, 'Border Tax Adjustments: A Feasible Way to Support Stringent Emission Trading’, 24:2 European Journal of Law and Economic (2007), 137.

${ }^{20}$ Whether or not rebates are provided for exports is a design issue depending on the economic outcome pursued. On this see S. Monjon and P. Quirion, n. 13 above, at pp 5201 et seq. An economic impact analyses of different design options is provided by S. Monjon and P. Quirion, Adressing leakage in the EU ETS: results from the CASE II model (Climate Strategies 2009).

${ }^{21}$ See the meta-analysis of 25 articles related to carbon leakage estimations by F. Branger and P. Quirion, 'Would Border Carbon Adjustments Prevent Carbon Leakage and Heavy Industry Competitiveness Losses? Insights from a Meta-analysis of Recent Economic Studies', 99 Ecological Economics (2014), 29.

${ }^{22}$ For an overview see K. Holzer, Carbon-related Border Adjustment and WTO Law (Edward Elgar 2014). For arguments in favour of the legal adjustability of carbon costs, see F. Biermann and R. Brohm, 'Border Adjustments on Energy Taxes: A Possible Tool for European Policymakers in Implementing the Kyoto Protocol' 74:2 Vierteljahreshefte zur Wirtschaftsforschung (2005), 249, at pp 251et seqq.; R. Ismer and K. Neuhoff, n. 19 above, 'Border Tax Adjustments: A Feasible Way to Support Stringent Emission Trading', 24:2 European Journal of Law and Economic (2007), 137, at pp 137 to 164; R. Ismer, n. 10 above, at p 419. For arguments against the legal feasibility of carbon costs, see R. Quick, 'Border Tax Adjustment' in the Context of Emission Trading: Climate Protection or 'Naked' Protectionism?', 3:5 Global Trade and Customs Journal (2008), 163, at pp 164 to 166. See also J. de Cendra, 'Can Emissions Trading Schemes Be Coupled with Border Tax Adjustments? An Analysis vis-à-vis WTO Law', 15:2 Review of European Community and International Environmental Law (2006), 131, at pp 139 et seqq; F. Sindico, 'The EU and Carbon Leakage: How to Reconcile Border Adjustments with the WTO?', 17:6 European Energy and Environmental Law Review (2008), 328, at p 337. On the 'like product' discussion in the context of the World Trade Organization, see e.g. F. Biermann and R. Brohm, Implementing the Kyoto Protocol without the Unites States, 4:3 Climate Policy (2005), 289, at p 291 et seqq; R. Quick and C. Lau, 'Environmentally Motivated Tax Distinctions and WTO Law: The European Commission's Green Paper on Integrated Product Policy in the Light of the 'Like Product-' and 'PPM-' Debate', 6:2 Journal of International Economic Law (2003), 419, at pp 424 to 436; C. Kaufmann and R. Weber, 'Carbonrelated Border Tax Adjustment: Mitigating Climate Change or Restricting International Trade', 10:4 World Trade Review (2011), 497, at pp 506 to 510. On the calculation of border carbon adjustments see, e.g., R. Ismer, n. 10 above, at p 420 et seqq; J. de Cendra, ibid, at p142. On the justification of border carbon adjustments see, e.g., R. Ismer and K. Neuhoff, ibid., at pp 149 to 152; R. Quick, ibid, at pp 168 to 174; C. Kaufmann and R. Weber, ibid, at p 511 to 520. On the administrative challenges see, e.g., R. Ireland, 'Implications for Customs of Climate Change Mitigation and Adaptation Policy Options: A Preliminary Examination', 4:2 World Customs Journal (2010), 21, at p 27et seqq.; S. Monjon and P. Quirion, n. 13 above, at p 5203 et seqq; M. Moore, 'Implementing Carbon Tariffs: A Fool's Errand?', 34:10 The World Economy (2011), 1679; D. Helm, The Carbon Crunch: How We're Getting Climate Change Wrong - And How to Fix It (Yale University Press 2012), at p 191. On the political feasibility see, e.g., T. Houser et al., Leveling the Carbon Playing Field: International Competition and US Climate Policy Design (Peterson Institute for International Economics and World Resources Institute 2008), at p 42; S. Dröge et al., n. 13 above, at p 55 and p 64. 
potential of Emissions Trading Systems (Inclusion of Consumption, in the following: IoC). ${ }^{23}$ In line with the destination principle, ${ }^{24}$ which is established for indirect taxes, the charge would apply only to consumption in the respective territory, regardless of the place of production. Such charge would be coupled with free allocation based on actual output, ${ }^{25}$ where emissions trading schemes are in place. Free allocation based on actual or recent production and an intensity benchmark, which could be calculated according to Best Available Technology within the EU, would deliver incentives for upstream emission reductions. The pass-through of carbon costs muted by $\mathrm{OBA}^{26}$ would then be re-established by the charge. The IoC would thus not be a carbon tax as suggested by others, ${ }^{27}$ but would operate in the realm of existing emissions trading schemes. ${ }^{28}$

The literature on the IoC is developing rapidly: while a working paper by Acworth et al. ${ }^{29}$ first elaborated on the idea more extensively, a short paper by Neuhoff et al. ${ }^{30}$ has summarized the underlying idea. Other articles have gone into more details regarding specific sectors $^{31}$ (cement, ${ }^{32}$ steel, ${ }^{33}$ as well as pulp and paper ${ }^{34}$ ). Pauliuk et al. have estimated the revenue generated from the IoC and its distribution among product categories. ${ }^{35}$ Munnings et al. have undertaken an international comparative approach regarding carbon pricing. ${ }^{36}$ They find that key elements of the IoC already exist in different carbon pricing systems, in

\footnotetext{
${ }^{23}$ For a summary of the literature see K. Neuhoff, R. Ismer et al., Inclusion of Consumption of carbon intensive materials in emissions trading - An option for carbon pricing post-2020 (Climate Strategies Report, May 2016).

24 On the destination principle see see OECD, Consumption Tax Trends - VAT/GST and Excise Rates, Trends and Policy Issues (OECD Publishing 2014), at pp 23 et seqq; OECD, International VAT/GST Guidelines (OECD 2015), at paras 1.8 to 1.15 .

${ }^{25}$ Basic information as well as a proposal for the implementation of dynamic allocation is provided by B. Borkent et al., Dynamic Allocation for the EU Emissions Trading System: Enabling Sustainable Growth (Ecofys 2014), at pp 7 et seqq and pp 24 et seqq.

${ }^{26}$ M. Grubb and K. Neuhoff, 'Allocation and Competitiveness in the EU Emissions Trading Scheme: Policy Overview’, 6:1 Climate Policy (2006), 7, at p 25; R. Ismer, n. 10 above, at p 180.

${ }^{27}$ Cf. T. Courchene and J. Allan, 'Climate Change: the Case for a Carbon Tariff/Tax, 29:3 Policy Options (2008), 59; G. Metcalf and D. Weisbach, 'The Design of a Carbon Tax', 33:2 Harvard Environmental Law Review (2009), 499; D. Marron and E. Toder, 'Tax policy Issues in Designing a Carbon Tax', 104:5 American Economic Review (2014), 563; C. McAusland and N. Najjar, 'The WTO Consistency of Carbon Footprint Taxes, 46:3 Georgetown Journal of International Law (2015), 765. An overview of carbon pricing schemes currently in place is given by $\mathrm{T}$. Tietenberg, $\mathrm{n}$. 13 above.

${ }^{28}$ It would thus complement the existing approaches for addressing leakage contained in Article 10a of the EU ETS Directive.

${ }^{29}$ W. Acworth, M. Haussner, R. Ismer and K. Neuhoff, Including consumption in the EU ETS - Administrative implementation of a consumption based charge (Climate Strategies Working Paper 2014). See also K. Neuhoff et al., Inclusion of Consumption of Carbon Intensive Commodities in Carbon Pricing Mechanisms (Climate Strategies Policy Paper 2015); K. Neuhoff et al., 'Leakage Protection for Carbon Intensive Materials Post 2020', 28/29 DIW Berlin Economic Bulletin 2015, 397.

${ }^{30}$ Cf. K. Neuhoff, R. Ismer et al., n. 23 above.

${ }^{31} \mathrm{~K}$. Neuhoff et al., (2015). 'Modernization and Innovation in the Materials Sector: Lessons from Steel and Cement’, 28/29 DIW Berlin Economic Bulletin (2015), 387.

${ }^{32}$ K. Neuhoff et al., Carbon Control and Competitiveness Post 2020: The Cement Report - Final Report (Climate Strategies 2014).

${ }^{33}$ K. Neuhoff et al., Carbon Control and Competitiveness Post 2020: The Steel Report - Final Report (Climate Strategies 2014).

${ }^{34}$ S. Roth et al., The Pulp and Paper Report - Sector analysis for the Climate Strategies Project on Inclusion of Consumption in Carbon Pricing, (Climate Strategies Overview Paper, May 2016).

${ }^{35}$ S. Pauliuk et al., Quantifying Impacts of Consumption Based Charge for Carbon Intensive Materials on Products (DIW Discussion Paper 1570, DIW 2016).

${ }^{36}$ C. Munnings et al., Experience with Pricing Carbon Consumption (RFF Discussion Paper 2016, forthcoming).
} 
particular in California, China and South Korea. In legal scholarship, Ismer and Haussner have shown that the IoC can be considered as an environmental regulation and can thus be implemented in Europe as part of the EU ETS Directive. ${ }^{37}$

Against this background, the present contribution considers the example of the EU Emissions Trading Directive and explores the precise legal design as well as the most important administrative aspects of such a charge. It argues that the IoC is, provided appropriate choices are made, ripe for implementation. It starts out by presenting the fundamental legal design choices that need to be made even when introducing the charge in a purely domestic context. This concerns the scope, rate, base of assessment and use of revenue. Furthermore, we show that selected economic agents should be given the option to profit from duty suspension arrangements. The concept, which is well established under excise duties, postpones the moment when the charge becomes due to the time of release for consumption (B.). For the international context, the paper contends that the IoC should follow the destination principle: ${ }^{38}$ while exports are relieved automatically where the exported good was held under duty suspension arrangements, design choices need to be made with respect to imports. In this respect, we argue that the charge should cover basic materials as well as carbon intensive intermediary and final products (C.). Duty suspension arrangements create both the need for determining who qualifies for participation in such arrangements and for elaborate monitoring, reporting and verification procedures. With respect to monitoring, the IoC should not follow the model implemented for high tax goods such as alcohol under excise duties, which are subject to stringent and permanent controls under the Excise Movement and Control System (EMCS). Instead, a simplified version would suffice (D.) The paper concludes with a summary and a brief outlook on a similar mechanism for a carbon tax (E).

\section{B. Fundamental Design Choices: The charge in a domestic context}

The fundamental design of the IoC is determined to a significant degree by the integration into the respective emissions trading system, such as the EU ETS. The policy choices which have been made when opting for the emissions trading system and which have been accepted by economic actors are not to be revisited. The IoC thus is not a fundamental alternative to an emissions trading system, but a complement, which fixes some of its deficits. The charge should be imposed only where the perceived need for free allocation of allowances implies that emissions trading fails to deliver an efficient solution for mitigation. Moreover, the design choices regarding the IoC should be exercised so as to approximate a situation under an emissions trading system in a world of equal carbon prices.

The close connection between the IoC and the respective emissions trading system implies that the widest possible scope of the IoC would be determined by the sectors deemed to be at risk of carbon leakage and thus profiting from free allocation (1.). Similarly, the calculation of

\footnotetext{
${ }^{37}$ R. Ismer and M. Haussner, 'Inclusion of Consumption into the EU ETS: The Legal Basis under European Union Law’, 25:1 Review of European, Comparative \& International Environmental Law (2016), 69.

${ }^{38}$ On the destination principle see see OECD, Consumption Tax Trends - VAT/GST and Excise Rates, Trends and Policy Issues (OECD Publishing 2014), at pp 23 et seqq; OECD, International VAT/GST Guidelines (OECD 2015), at paras 1.8 to 1.15 .
} 
the payable amount under the charge would depend on the base of assessment and on the applicable rate, both of which are narrowly related to the emissions trading system: the base of assessment for the charge under the IoC would follow product-specific benchmarks. Such benchmarks are already used for free allocation of allowances under the EU ETS, which is the biggest global carbon market to date and which for illustrative purposes will be referred to in the following. The applicable rate would be governed by the market price of allowances (2.). The chargeable moment would be determined in line with excise duties: while the liability would already be created when the basic material in question such as steel has been produced, it would become due only once the good is released for consumption. At the same time, the corresponding technical fix - the above-mentioned duty suspension arrangements - would reduce the potential for fraud (3.). Finally, the use of revenue once again would mirror general choices made in the EU ETS at large (4.).

\section{Scope}

The scope of the IoC would be determined primarily by the purpose of the IoC as a complement to free allowance allocation. The IoC would thus be limited to sectors which are deemed to be at risk of carbon leakage. According to Article 10a(15) and (16) of the EU Emission Trading Directive, the sectors must be carbon-intensive and/or have a large exposure to international trade. The former criterion requires that the direct and indirect additional costs induced by the implementation of this Directive lead to a substantial increase of production costs, whereas the intensity of trade with third countries is defined as the ratio between the total value of exports to third countries plus the value of imports from third countries and the total market size for the Community. Thus, the work undertaken in order to identify sectors at risk of leakage can be referred to. ${ }^{39}$

Nonetheless, opening the path for the combination of dynamic free allocation and the IoC would not imply that this would have to be the only mechanism. On the contrary, it is conceivable that this mechanism be either initially or permanently confined to certain sectors only, whereas other sectors would profit from one of the other leakage protection measures currently foreseen by the EU ETS Directive. ${ }^{40}$

\section{Calculation of liability}

The amount of the liability depends on two factors: the base of assessment and the applicable rate. Both parameters should be generally aligned with the corresponding values from the emissions trading systems, such as the EU ETS. However, simplifications are warranted in order to ensure a more cost efficient administration.

\footnotetext{
${ }^{39}$ Cf. e.g. J. Reinaud, Issues behind competitiveness and carbon leakage (IEA Information Paper, OECD and IEA 2008); Mohr et al., Trade flows and cost structure analysis for exposed industries in the EU-27 (Climate Strategies 2009). S. Monjon and P. Quirion, n. 13 above, at p 23 et seq. H. Bolscher et al., Carbon Leakage Evidence Project - Factsheets for selected sectors (ECORYS 2013); I. Juergens et al., 'Identifying carbon leakage sectors in the EU ETS and implications of results', 13:1 Climate Policy (2013), 89; A. Marcu et al., n. 13 above, at pp 4 et seqq.

${ }^{40}$ See Article 10b(1) of the Emissions Trading Directive.
} 


\section{Base of assessment}

The base of assessment should be related to the carbon content of the covered materials. Indeed, from a purely environmental perspective, the carbon content should be determined by the emissions associated with a single product. Materials produced with environmental friendly technology would then gain a competitive advantage over less efficiently produced materials.

Yet administrative feasibility militates against such individualized determination of a product's carbon content. ${ }^{41}$ Otherwise, production processes would have to be monitored and emissions would have to be allocated to specific products, which would imply compliance efforts going significantly beyond those required under current EU ETS rules. The problem would be further exacerbated for imports. ${ }^{42}$ In this case, information might not be available to governments about the production processes deployed and their emissions. ${ }^{43}$ Within the debate on BCA, two alternative approaches have been proposed in order to deal with the issue: while some scholars have argued that the average emissions of domestic producers should be used to determine the carbon content of imports where no information about a product's emissions are available, ${ }^{44}$ others have spoken out in favour of an adjustment at the level of best available technology (BAT). ${ }^{45}$ Both approaches would also be conceivable under the IoC.

In any event, the carbon content should be determined according to material specific benchmarks ${ }^{46}$ already used for free allocation of allowances that are independent of the actual production process. ${ }^{47}$ At first glance, there would seem to be no motivation for efficiency improvements as the charge would only reflect emissions based on BAT. However, in combination with dynamic free allocation a different picture emerges: All producers would receive allowances corresponding to BAT. To this extent, there would be no opportunity costs of production and thus no cost pass-through down the value chain. ${ }^{48}$ The producers of basic materials would, however, be exposed to carbon costs corresponding to carbon intensity above BAT and thus face incentives for carbon efficiency improvements.

\footnotetext{
${ }^{41}$ Approaches how to implement charges that are directly linked to the real carbon footprint of products and their difficulties are described by C. McAusland and N. Najjar, n. 27 above, at p 770.

42 See below at C.II.

${ }^{43}$ See for a similar discussion: S. Monjon and P. Quirion, n. 13 above, at pp 5203 et seq; G. Metcalf and D. Weisbach, n. 27 above, at p 549.

${ }^{44}$ S. Monjon and P. Quirion, n. 13 above, at p 5204; A. Cosbey et al., A Guide for the Concerned: Guidance on the elaboration and Implementation of border carbon adjustment (Policy Report 03, Entwined 2012), at p 15.

${ }^{45}$ O. Godard, Unilateral European post-Kyoto climate policy and economic adjustment at EU borders (Cahier No DDX 07-15, EDF-École Polytechnique 2007), at p 14; R. Ismer and K. Neuhoff, n. 19 above, at pp 155 et seqq.

${ }^{46}$ These benchmarks are based on emissions associated with the 10 per cent best-performing installations in the European Union ( $c f$. Art. 10a(2) of the Emissions Trading Directive).

${ }^{47}$ Such an approach was also suggested by S. Monjon and P. Quirion for the determination of the carbon content of imports (n. 13 above, at p 5204).

${ }^{48}$ M. Grubb and K. Neuhoff, n. 26 above, at p 25; R. Ismer, n. 10 above, at p 180.
} 
2. Rate

In an ideal world, the rate of the charge should reflect the social marginal damage from producing an additional unit of the product or better from consuming an additional unit of the product. ${ }^{49}$ Yet the assessment of the social marginal damage is difficult. ${ }^{50}$ Thus, recourse is taken to alternative methods like the calculation of rates that are necessary for reaching future climate targets. ${ }^{51}$ The tax rate would then be set at a level where investment in abatement technology is incentivized. ${ }^{52}$

This approach is also inherent in the EU ETS, where a future emissions target is implemented through the limited number of emissions allowances. Auctioning these allowances off at the auction platforms or allowing trade then puts a price on allowances that equals the marginal costs of abatement. ${ }^{53}$ As there is already a price per ton of carbon in the $\mathrm{EU}$, there is no need to determine an extra rate applicable under the IoC. Rather, the rate under the IoC should be determined by the allowance price at the auction platforms.

Yet, there should be no real time connection between the rate under the IoC and the price of carbon allowances. Admittedly, such connection would promise the advantage of automatic adjustments of the rate where new information becomes available about the marginal costs of abatement. ${ }^{54}$ However, a permanent real time adjustment to the current carbon price would entail high administrative and compliance costs for the government and the companies involved. ${ }^{55}$ It therefore appears preferable to apply a yearly average carbon price as for example revealed by the clearing price of allowances in public auctions. The exact figure, which should be published yearly by the European Commission together with other yearly adjustments made in the trade context, ${ }^{56}$ could then be incorporated into the relevant IT processes.

Summing up, the charge, which is determined by allowances prices, and the intensity benchmark used for free allocation would reinstate the carbon price signal that had been

\footnotetext{
${ }^{49}$ A. Pigou, The Economics of Welfare (4th edn, Macmillan \& Co LTD 1962), Part II, Chapter III on the values of marginal social net products and the size of the national dividend; G. Metcalf and D. Weisbach, n. 27 above, at pp 511 et seqq; D. Marron and E. Toder, n. 27 above, at p 563.

${ }^{50}$ D. Marron and E. Toder, n. 27 above, pp 563 et seq.

${ }^{51}$ See the seminal paper by W. Baumol and W. Oates, 'The Use of Standards and Prices for Protection of the Environment' 73:1 The Swedish Journal of Economics (1971), 42; G. Metcalf and D. Weisbach, n. 27 above, at p 512; D. Marron and E. Toder, n. 27 above, at p 564.

${ }^{52}$ G. Metcalf and D. Weisbach, n. 27 above, at pp 511 et seqq; D. Marron and E. Toder, n. 27 above, at p 518.

${ }^{53}$ Cf. Commission, 'Green Paper on greenhouse gas emissions trading within the European Union' COM(2000) 87 final, at pp 7 et seqq; R. Ismer, n. 10 above, at pp 106 et seq; G. Metcalf and D. Weisbach, n. 27 above, at pp 519.

${ }^{54}$ Cf. G. Metcalf and D. Weisbach, n. 27 above, at pp 519 et seqq; D. Marron and E. Toder, n. 27 above, at p 564.

${ }^{55}$ G. Metcalf and D. Weisbach, n. 27 above, at pp 519 et seq spoke out for less frequent changes, where costs to changes are involved, as there is little benefit from an adjustment of rates in the short run as investment decisions are taken in the long run.

${ }^{56}$ As the IoC also applies on imports that are declared at the frontier, it is conceivable to publish the carbon price in combination with the yearly update of the combined nomenclature. See Art. 12 of the Council Regulation (EEC) No 2658/87 of 23 July 1987 on the tariff and statistical nomenclature and on the Common Customs Tariff [1987] OJ L 256, 1.
} 
muted by dynamic free allocation. The carbon costs associated with a product would thus equal the result of full auctioning in a world of equal carbon prices.

\section{Differentiation between time of creation of liability and the time when liability becomes due: the role of duty suspension arrangements}

In theory, the charge under the IoC could be imposed at different stages of the value chain. It could either be imposed purely upstream, i.e. when carbon intensive materials are produced, when they leave the premises on which they were produced, or when they are imported. Alternatively, the charge could be levied only downstream, when carbon intensive materials are supplied to final consumers. While both options would deliver incentives for substitution and an efficient use of material, they suffer from significant drawbacks:

In the upstream case, the charge would have to be rebated upon exportation according to the content of carbon intensive materials contained. Although this approach would comply with World Trade Law that does allow for rebates of inputs consumed during the production process, this approach should be discarded for two reasons. First, depending on the production stage of a product, rebates would be provided to actors that have not paid the charge. As there would be no document to prove the payment of the charge from the third production stage downwards, and indeed the rebate would not depend upon such payment, there would be a high risk of fraud, which vexes tax administrations under VAT. ${ }^{57}$ Companies could be incentivized to over-state the materials content of a product upon export to gain high rebates. Strict assessment of the materials content at the frontier could reduce this risk. However, this assessment would be linked to high administrative costs. The risk of over-rebates would rise, if the rate of the charge increases over time. Then, even in the case that the materials content is stated correctly, rebates would exceed the amount that once had been collected upstream. Thus, where there is a design that avoids rebates, this design should be chosen.

Admittedly, rebates could be avoided if the charge were exclusively imposed downstream, i.e. at the time when a product is supplied for final consumption. The charge would then follow the model of retail sales tax. Retail sales taxes - as opposed to VAT - are charges that are imposed at the very last stage of the supply chain. ${ }^{58}$ Until then, no liability to the tax has been created and accounted for. Hence, there would be no rebates for exports necessary to impose the destination principle. However, retail sales taxes suffer from significant disadvantages: First, authorities would have to monitor a huge number of participants in the scheme with corresponding administrative costs. Second, there would be excessive monitoring required to ensure that the correct amount of money had been charged and remitted by the retailer, as the audit and invoice trail is poor. ${ }^{59}$ In particular, the

\footnotetext{
${ }^{57}$ On carrousel fraud models under VAT see e.g. M. Frunza, Fraud and carbon markets: the carbon connection (Routledge 2013); M. Richardson, 'Fighting Tax Fraud and Tax Evasion in the EU: The 2012 Action Plan', 24:4 EC Tax Review (2015), 220; L. van der Hel-van Dijk and M. Griffioen, 'Tackling VAT-Fraud in Europe: A Complicated International Puzzle', 44:4 Intertax (2016), 290.

${ }^{58}$ On main design features of retail sales taxes see OECD, Consumption Tax Trends - VAT/GST and Excise Rates, Trends and Policy Issues (OECD Publishing 2014), at pp 21 et seq.

${ }^{59}$ OECD, n. 58 above, at p 21.
} 
determination of the right materials content would be difficult to assess, as there would be no document to rely on that would state the correct materials content.

Instead, a hybrid solution should be implemented that would follow the model of excise duties and differentiates between the creation of the liability on the hand and the moment when the liability actually becomes due. In general, excise duties are taxes on the consumption of specific goods and assessed according to the weight, volume, strength or quantity of a certain product. Their main difference to retail sales taxes is that liability to the charge is created upon production or importation. However, the charge is normally not due until goods are released for consumption (taxing point). ${ }^{60}$

The distinction between the creation of the liability on the hand and the moment when the liability actually becomes due on the other hand could be implemented by means of duty suspension arrangements. ${ }^{61}$ Duty suspension arrangements are fiscal arrangements which suspend the charge. Although liability to the charge has been created upon production, the charge is not due as long as goods are held under such arrangements. ${ }^{62}$ Duty suspension arrangements allow authorised entities to produce, process, hold, transport and trade excise goods between producers of different production stages without triggering excise. The duty is transferred along the supply chain until excise goods are finally released for consumption. When excise goods depart from suspension arrangements or are held, produced or imported outside such arrangements, they are deemed to be released for consumption and duty has to be paid. The duty must be paid by the person releasing excisable goods from duty suspension arrangements. $^{63}$ For this purpose, registered entities must submit periodic returns to the relevant national authorities and pay any charges due. To ensure fiscal supervision and effective monitoring of excise goods ${ }^{64}$, duty suspension arrangements only apply to goods which are produced, processed and held within tax warehouses ${ }^{65}$ and which are moved between warehouses or other registered entities. Tax warehouses have traditionally been spatially defined areas. ${ }^{66}$ In the case of the movement of excise goods, duty suspension

\footnotetext{
${ }^{60}$ See Article 7 of the Council Directive 2008/118/EC of 16 December 2008 concerning the gernal arrangements for excise duty and repealing Directive 92/12/EC [2009] OJ L9, 12 (Excise Directive). On this in the European Union context see M. Bongartz, 'Trade in goods subject to excise duties which have been released for consumption in other Member States', 6:2 World Customs Journal (2012), 19; H. Jatzke, 'Production, holding and movement of excise goods under duty suspension within the European Union', 6:2 World Customs Journal (2012), 3. See also R. Preece, 'Key controls in the administration of excise duties', 2:1 World Customs Journal (2008), 73, at p 75. On excise in general see OECD, n. 58 above, at pp 22 et seq.

61 Cf. Art. 4 No 7 of the Excise Directive.

${ }^{62}$ H. Jatzke, n. 60 above, at pp 3 et seq.

${ }^{63} \mathrm{Cf}$. Article 8(1) of the Excise Directive.

${ }^{64}$ H. Jatzke, n. 60 above, at p 4.

65 A tax warehouse is defined as "a place where excise goods are produced, processed, held, received or dispatched under duty suspension arrangements by an authorised warehouse keeper in the course of his business, subject to certain conditions laid down by the competent authorities of the Member State where the tax warehouse is located" (Article 4 No 11 of the Excise Directive).

${ }^{66}$ Cf. Article 4 No 11 of the Excise Directive; Sec. 4, Sec. 3 By-law on the German Excise Act on Beer; Irish Tax and Customs, Authorisation of Warehouse keepers and Approval of Tax Warehouses Manual, chapter 3.2 on tax warehouse premises and activities.
} 
arrangements apply if excise goods are moved between tax warehouses or between a tax warehouse and a registered consignee ${ }^{67}$.

Applying this approach to the IoC would mean that the liability to the charge would be created upon production of carbon intensive materials. This liability could then be passed along the value chain under duty suspension arrangements. The charge would however become due only once the product has been released for consumption. The charge would be imposed according to the materials content of the product, the emissions benchmarks and the rate of the charge at the time of release for consumption. Once the charge would have been settled, the liability would be acquitted and thus cease to exist.

Drawing on the experience with the excise system, the IoC could work as follows. Producers, manufactures or traders desiring to handle carbon intensive products under duty suspension arrangements, would have to seek authorization. If products comprising carbon intensive materials were stored, held or processed by registered companies, no charge would be levied. Similarly, when such products were traded between two authorized persons, these products could be placed under suspension arrangement and no duty would be charged. When these products were sold to unregistered entities or to the final consumer, the good would be assumed to have been released for consumption and the charge would have to be levied by the registered entity and passed onto the consumption price.

The excise approach has significant advantages compared both to an early imposition of the charge and to a retail tax. First, as no rebates are provided, there would be no risk of over-rebates. Second, in comparison to retail sales taxes, carbon intensive material would be subject to fiscal supervision from the creation or import of carbon intensive materials to the imposition of the charge. Fiscal supervision would therefore create invoice trails that would allow for the auditing of liabilities along the value chain. Accordingly, the risk of fraud would be limited. All this means that the chargeable moment should be determined in line with excise duties: while the liability would be already created when the basic material in question such as steel has been produced, it would become due only once the good is released for consumption.

\section{Use of revenue}

The revenue, which Pauliuk et al. have calculated as 17 bn Euros per year, ${ }^{68}$ would be collected by the Member State where the product is released for final consumption. For reasons of legal feasibility under Article 192(1) and (2) TFEU, the IoC would have to be qualified as an environmental regulation rather than a provision primarily of fiscal nature. In order to lend further support to such qualification, the revenue should not flow into the general budget. ${ }^{69}$ Instead, the money raised would be allocated to special funds, for example,

\footnotetext{
67 “'[A] registered consignee’ means a natural or legal person authorised by the competent authorities of the Member State of destination, in the course of his business and under the conditions fixed by those authorities, to receive excise goods moving under a duty suspension arrangement from another Member State;” (Article 4 No 9 of the Excise Directive).

${ }^{68}$ S. Pauliuk et al., Quantifying Impacts of Consumption Based Charge for Carbon Intensive Materials on Products (DIW Discussion Paper 1570, DIW 2016): total revenue in Europe generated by the charge for a carbon price of 30 Euros per ton of carbon).

${ }^{69}$ For details see R. Ismer and M. Haussner, n. 37 above.
} 
in the country in which the goods were released for consumption. They could be placed under the roof of an established organization. Alternatively, new entities could be set up. The funds would use the revenue in the first place for purchasing allowances on the carbon markets to cover net imports. In such a way, all emissions linked to carbon-intensive products consumed within the EU would be covered by allowances. The remainder of the funds would support climate mitigation or adaptation measures. The decisions on the exact usage of the funds, which would then have to be in line with EU State aid rules, as well as on the exact governance structures could be taken at the national level.

\section{The Charge in the International Context: Exports and Imports}

In the international context, the charge should be implemented in accordance with the destination principle. ${ }^{70}$ This concept well-established for indirect taxes means that only consumption in the EU would be covered by the charge. Exports would be relieved of the charge, whereas imports would be subject to the charge at a level reflecting their content of carbon intensive materials. The destination principle would automatically be applied where the exported goods were held under duty suspension arrangements (1.). By contrast, the liability to the charge would be created for imports according to the content in the relevant basic materials, the emissions benchmark and the applicable rate. As for the case of production, imported goods could also be held under a duty suspension arrangement. The charge would then be suspended until the release for consumption. The scope of imported goods giving rise to the charge should neither be limited to the scope of materials covered by the charge upon production nor comprehensively be applied to all imported goods. In order to ensure environmental integrity at reasonable carbon administrative and compliance costs, the charge should instead apply only to the importation of goods in pre-defined product categories which have an elevated content of carbon intensive primary materials (2.).

\section{Relief for Exports}

Relief for exports would be automatic, but somewhat incomplete: it would be limited to situations where the exported goods were held under duty suspension arrangements. Upon exportation, the liability to the charge regarding the goods under duty suspension would be acquitted. Thus, the charge, which was created upon production, would not come due. By contrast, there would be no relief for goods that were not held under duty suspension arrangements. Since the charge would already have both been created and become due and there would, as pointed out above, be no rebates, the charge would have become final. Indeed, the fact that exports would be relieved from the charge only where the goods were held under duty suspension arrangements, would determine the choice of economic agents whether or not to participate in such arrangements: The agents would have to balance the advantage from the relief on the one hand and the compliance costs of participation on the other hand.

\footnotetext{
70 OECD, Consumption Tax Trends - VAT/GST and Excise Rates, Trends and Policy Issues (OECD Publishing 2014), at pp 23 et seqq; OECD, International VAT/GST Guidelines (OECD 2015), at paras 1.8 to 1.15.
} 
Such relief, which would be in conformity with the destination principle, complies with the obligations under world trade law, as long as no subsidy would be granted. ${ }^{71}$ As the 1970 report on border tax adjustments stated, adjustments made for taxes and charges that are directly levied on products - or directly on the materials going into the manufacture of such goods - qualify for export exemptions or remissions. However, the exemption or remission should not exceed an amount that would be levied in respect of the production and distribution of like products when sold for domestic consumption. ${ }^{72}$

The underlying rationale for adjustments at the border for indirect taxes is the following: The purpose of world trade law is trade neutrality, both on the import and the export side. Where taxes and charges focus on internal consumption, there is no need to levy such charges on exports, as they are not destined for domestic consumption. Rather, they should be subject to internal charges in the country of destination. Imposing indirect taxes on exports would impose additional costs on exports and thus would oppose trade neutrality. ${ }^{73}$

\section{Including imports: Focusing on basic material and intermediary and final products with significant shares of these materials}

In order to ensure that the consumption of carbon intensive goods within the territory of the EU would be covered irrespective of where the goods had been produced, the liability to the charge would also be created for imports. It would be calculated in accordance with the principles set out above for the liability created from the production. As is the case for production, imported goods could also be placed under a duty suspension arrangement upon importation. The charge would then again be suspended until the release for consumption. Where no duty suspension arrangements applied, the charge would be due immediately upon importation.

The scope of imported goods giving rise to the charge should not be limited to the scope of materials covered by the charge upon production. Such a limited scope would be too narrow as carbon embodied in the trade of goods down the value chain would be ignored. ${ }^{74}$ Rather, all imported carbon intensive materials as well as imports containing such materials should be included in the scheme at first. However, for reasons of administrative feasibility, it would be conceivable to apply de minimis rules to the importation of goods in selected product categories. $^{75}$ This means that no liability to the charge would be created upon importation of goods that are subject to such de minimis rules.

\footnotetext{
${ }^{71}$ Reliefs for export are governed by Article XVI:4, VI:4 of the General Agreement on Tariffs and Trade (GATT, World Trade Organization 1994) and the Agreement of Subsidies and Countervailing Measures (ASCM, World Trade Organization 1994).

${ }^{72}$ World Trade Organization, 'Report by the Working Party on Border Tax Adjustments of 20 November 1970' L/3464, Annex - Note by the Secretariat, paras 20 to 36. Cf. R. Ismer and K. Neuhoff, n. 19 above, at 144 et seq.

${ }^{73}$ Cf. World Trade Organization, n. 72 above, at para 9.

${ }^{74}$ Further, such an approach would shift carbon leakage concerns to the next level of the value chain (S. Monjon and P. Quirion, n. 13 above, at p 5203).

${ }^{75}$ Cf. on this see A. Cosbey et al., n. 44 above, at pp 12 et seq.; S. Monjon and P. Quirion, n. 13 above, at p 5203.
} 
The relevant goods in selected product categories to which de minimis rules apply could be chosen based on the share of carbon costs relative to the product value. According to Pauliuk, ${ }^{76}$ the creation of liability upon import can be restricted to around 1000 product categories of the Harmonized Commodity Description and Coding System (HS), less so if fewer commodities are covered. In doing so, around 85 per cent of imported emissions associated with carbon intensive material would be covered by the scheme. ${ }^{77}$ As under the identification of sectors at risk of leakage, the relevant product categories that could be determined by the European Commission. ${ }^{78}$

From a more technical perspective, information concerning the creation of liability upon importation could be integrated into TARIC (Tarif Intégré des Communautés Européennes) - the integrated Tariff of the European Union. The TARIC is a source of data created by the European Commission that shows the rules applicable to the importation of products. ${ }^{79}$ It summarizes the harmonized system, the combined nomenclature and other matters related to imports for the different product categories. Although it does not have any legal status, the TARIC number is used to classify goods for customs declarations. ${ }^{80}$ The number stated in the customs declaration then determines the rules applicable on imports. Accordingly, integrating information about the creation of liability into TARIC would allow customs officials and importers to see whether or not a liability is created upon importation and what additional procedures would apply.

The extension to imports would be compliant with world trade law. In particular, it would satisfy the National Treatment Requirements under Article III.2 of the General Agreement on Tariffs and Trade $\left(\right.$ GATT) ${ }^{81}$, which prohibits any discrimination against imported products. ${ }^{82}$ This is because the charge would apply without difference to materials both imported and domestically produced. The level of the charge would depend only on the physical properties of the material subject to the charge and not on the production process. ${ }^{83}$

\footnotetext{
${ }^{76}$ S. Pauliuk et al., n. 68 above, at pp 21 et seqq.

${ }^{77}$ See figure 7 and 8 in S. Pauliuk et al., n. 68 above, at p 23 et seq.

${ }^{78}$ See Art. 10a(13) of the Emissions Trading Directive.

${ }^{79}$ T. Lyons, EC Customs Law (2nd edn, Oxford University Press 2008), at p 145.

${ }^{80}$ Ibid.

${ }^{81}$ Thus, there would be no need for applying an exception under Article XX (b) and (g) GATT. Cf. e.g. J. Pauwelyn, U.S. Federal Climate Policy and Competitiveness Concerns: The Limits and Options of International Trade' (Working Paper, Nicholas Institute for Environmental Policy Solutions - Duke University 2007), at pp 33 et seqq; R. Weber, 'Border Tax adjustment - legal perspective', 133:3 Climatic Change (2015), 407, at pp 415 et seqq; R. Ismer and K. Neuhoff, n. 19 above, at pp 149 et seqq.

${ }^{82}$ At first glance, one may wonder whether the fact that for the domestic case, only the production of certain basic materials is covered, whereas the liability is also created upon importation of products further down the value chain, discriminates against foreign producers. However, this would be a fallacy. In truth, the amount of the charge borne by the release for consumption of foreign products is the same as for like domestic products where the materials contained in the product had been held under a duty suspension arrangement prior to the release for consumption. This is because the charge is in both cases measured according to the basic materials content.

${ }^{83}$ On this see e.g. J. Pauwelyn, n. 81 above, at pp 27 et seqq; P R. Weber, n. 81 above, at pp 412 et seqq; J. Trachtman, WTP Law Constraints on Border Tax Adjustment and Tax Credit Mechanisms to Reduce the Competitiveness of Carbon Taxes (Discussion Paper RFF DP 16-03, Resources for the Future 2016), at pp 11 et seqq;
} 
This means that "like" materials would be treated without any discrimination irrespective of their origin. Neither is there an arbitrary discrimination against directly competitive or substitutable product, as the amount of the charge under the IoC would depend in a linear manner on the carbon content of the materials in question. ${ }^{84}$ The extension to the importation of products down the value chain would not constitute a discrimination either: the level of the charge, if levied at all in such case, would exclusively reflect the carbon content of the basic materials contained in the product - which for domestic products would have been subject to the charge, be it upon production or upon release for consumption if held under duty suspension arrangements. Quite on the contrary, it would even be legally possible, albeit not administratively feasible, to levy the charge on all imports (with respect to their content of the relevant basic materials) rather than those with an elevated carbon intensity.

\section{Administrative Aspects}

The administration of the scheme should be designed in a way that ensures a sufficient level of compliance at minimal administrative and compliance costs. For that purpose, the established role model of excise should be followed. Reporting arrangements and functioning should be similar to excise and VAT, for which operating costs remain below $5 \%$ of the tax revenue. ${ }^{85}$ Indeed, given the fact that reporting and monitoring requirements of the IoC can be incorporated into existing reporting structures, synergy effects may further limit operating costs of the proposed charge.

In particular, duty suspension arrangements create the need for determining who qualifies for participation in such arrangements i.e. who can qualify as an authorized person (1.). At the same time, elaborate monitoring, reporting and verification procedures become necessary. With respect to monitoring, the IoC should not follow the model implemented for high tax goods such as alcohol under excise duties, which are subject to stringent and permanent controls under the Excise Movement and Control System (EMCS). Instead, a simplified version, which can be found for lower value excises, would suffice.

\section{Authorized persons}

Drawing from the experience in the excise sector, the determination of who is authorized to participate in the scheme is paramount for its effective and efficient operation. The authorization requirement serves the dual purpose of (i) ensuring that the economic agents meet their obligations under the IoC, so that in particular they effectively pay any charge due which they owe and (ii) allowing flexibility for economic agents to self-select on participation so as to reduce compliance and administrative costs.

\footnotetext{
${ }^{84}$ See Note Ad Article III:2 GATT as well R. Ismer and K. Neuhoff, R. Ismer and K. Neuhoff, n. 19 above, at pp 148 et seq; Japan-Taxes on Alcoholic Beverages, Report of the Appellate Body, adopted on 1 November 1996, WT/DS8/AB/R, WT/DS10/AB/R, WT/DS11/AB/R; Korea-Taxes on Alcoholic Beverages, Report of the Appellate Body, adopted 17 February 1999, WT/DS75/AB/R,WT/DS84/AB/R; Chile-Taxes on Alcoholic Beverages, Report of the Appellate Body, adopted 12 January 2000, WT/ DS87/AB/R, WT/DS/110/AB/R.

${ }^{85}$ KPMG, Administrative Burdens - HMRC Measurement Project, 2006; HM Revenue \& Customs, Annual Report and Accounts 2014-15 (HM Revenue \& Customs 2015).
} 


\section{Ensuring compliance}

Authorization helps to ensure that the amount of charge due is effectively paid. ${ }^{86}$ Under duty suspension arrangements, the liability of the charge may be transferred from one economic operator to another. ${ }^{87}$ Thus, there is a risk that the charge may be evaded or not paid for other reasons, such as insolvency. At the same time, it needs to be ascertained that actors may actually handle carbon intensive products under duty suspension in a reliable manner. Authorization allows dealing with these concerns through a risk-assessment and a preselection of actors. ${ }^{88}$

One principle of authorization that is also applied under excise law is granting authorization only to actors without objection regarding their tax reliability. ${ }^{89}$ This means that authorization is based - among other criteria - on details of the company's financial position, its revenue history and its compliance with other fiscal obligations (customs, VAT, direct taxation). Consequently, past behaviour is used as an indicator of future compliance. The advantage of such an approach is that information about past behaviour in tax matters is accessible to national authorities and no additional administrative burden is put on economic operators. In case of insufficient tax reliability, the applicant has to provide a guarantee based on the average liability held in his company. ${ }^{90}$

Authorization under the IoC should be granted to natural or legal persons by application. Upon application, the applicant would have to provide data about his tax reliability to the competent national authority. The applicant could either provide these data voluntarily or he could consent that the competent authority can retrieve the necessary data from the tax administration.

Economic actors that are already authorized for similar fiscal matters could be deemed to fulfil the criterion regarding their tax reliability. One such fiscal concept is "authorized economic operators" (AEO). The idea of AEOs is to simplify customs procedures and to reduce administrative burdens. ${ }^{91}$ This appears particularly appealing as most major European companies are already registered as AEOs. ${ }^{92}$ The requirements under AEO authorization

\footnotetext{
${ }^{86} \mathrm{Cf}$. R. Preece, n. 60 above, at p 78.

${ }^{87}$ H. Jatzke, n. 60 above, at $\mathrm{p} 3$.

${ }^{88}$ R. Preece, n. 60 above, at pp 78 et seq; M. Bongartz and S. Schroer-Schallenberg, Verbrauchsteuerrecht (2nd edn, C.H. Beck 2011), at paras D17 et seq.

${ }^{89}$ M. Bongartz and S. Schroer-Schallenberg, n. 88, at para D17.

90 On the authorisation under excise law see Commission Recommendation of 29 November 2000 [2000/789/EC] setting out guidelines for the authorisation of warehouse keepers under Council Directive 92/12/EEC in relation to products subject to excise duty (notified under document number C(2000) 3355) [2000] OJ L 314, 29; HM Revenue \& Customs, Excise Notice 196: excise goods - registration and approval of warehousekeepers, warehouse premises, owners of goods and registered consignors (UK HM Revenue and Customs 2016 update), chapter 2 on approvals, authorisations and registrations and chapter 4 on authorization of excise warehousekeepers.

${ }^{91}$ Cf. Art. 38(1) and (2) of the Regulation (EU) No 952/2013 of the European Parliament and of the Council of 9 October 2013 laying down the Union Customs Code (recast) [2013] OJ L 269, 1 (UCC); European Commission, 'Authorised Economic Operators - Guidelines' TAXUD/B2/047/2011-Rev.5, at pp 16 et seqq.

${ }_{92} \mathrm{~A}$ list of companies can be found at http://ec.europa.eu/taxation_customs/dds2/eos/aeo_consultation.jsp?Lang=en\&holderName=\&aeoCountry=\&cer tificatesTypes $=$ AEOC \&certificatesTypes $=$ AEOF\&certificatesTypes $=$ AEOS\&Expand $=$ true $\&$ offset $=1 \&$ showRec
} 
procedures fully satisfy the needs of fiscal security and risk assessment under the IoC. In order to receive the status of an AEO the applicant has to provide among other things ${ }^{93}$

- the absence of any serious infringement or repeated infringements of customs legislation and taxation rules, including no record of serious criminal offences relating to the economic activity of the applicant,

- the demonstration by the applicant of a high level of control of his or her perations and of the flow of goods, by means of a system of managing commercial and, where appropriate, transport records, which allows appropriate customs control

- financial solvency, which shall be deemed to be proven where the applicant has good financial standing, which enables him or her to fulfil his or her commitments, with due regard to the characteristics of the type of business activity concerned.

When authorization is granted, an individual authorization number would be issued to the applicant for the purpose of identification. This number would be collected in a Europe-wide database accessible to national authorities and authorized persons. ${ }^{94}$

\section{Limiting the number of participants}

In order to keep administrative and compliance costs at a reasonable level, the number of participants participating in duty suspensions arrangements should be limited. The authorization requirements would contribute to achieving that goal: In our view, only actors conducting certain activities with carbon intensive commodities (importation, production, processing, trade) would need to participate in the scheme. Under the IoC, this comprises domestic producers of carbon intensive materials as liability to the charge is created at this stage. Further, economic operators dealing with carbon intensive materials (manufacturing industry) should qualify for authorization. By contrast, wholesalers and retailers serving domestic consumers in principle would not need to qualify for authorization.

The authorization requirement would moreover have a beneficial self-selection effect that would reduce the number of participants in the scheme: even if they qualified for authorization, actors with relatively little exposure to the charge might prefer not to apply for authorization. The benefits of participation tend to be reduced down the value chain and largely vanish for firms that do not export their products

\section{Monitoring, reporting and verification}

Procedures under the IoC need to be structured so as to ensure compliance As duty suspension arrangements allow for the transfer of liabilities along the value chain, efficient control mechanisms need to be in place in order to ensure that no liabilities are acquitted unlawfully. At the same time, administrative and compliance costs must not be excessive. We therefore advocate a transaction-based approach for monitoring (1.). Under this approach, the

ordsCount $=0$. This list of companies comprises e.g. BMW, Volkswagen, Peugeot, Volvo, HeidelbergCement, Holcim (Süddeutschland) GmbH, ThyssenKrupp, ArcelorMittal.

${ }^{93}$ Art. 39 of the UCC.

${ }^{94}$ Such a database (System for Exchange of Excise Data) is also implemented under excise law. See Art. 22 of the Council Regulation (EC) No 2073/2004 of 16 November 2004 on administrative cooperation in the field of excise duties [2004] OJ L 359, 1. On the functioning of the System of the System for Exchange of Excise Data see H. Jatzke, n. 60 above, at p 5. 
information required by the government in the administration of the scheme is limited and readily verifiable (2.).

\section{Transaction-based approach for monitoring}

The traditional approach for monitoring liabilities under consumption-based charges is based on a mixture of documentation and physical controls, where ingoing and outgoing goods are entered into stock accounts and transactions are documented by commercial documents. Transactions are then audited based on the documentation provided and stock accounts are verified by physical audits. ${ }^{95}$ Applying this approach to the IoC would be linked to high administrative costs and would be barely feasible as it requires that the exact amount of liability can be first allocated to intermediary and final products stored and that the liability can then be verified by physical audits.

New transaction-based approaches have evolved that focus on documentary and accountsbased processes that comprise risk management and post-transaction audits to monitor trade flows and stocks. Instead of conducting physical audits, the internal control system of companies is audited to ensure that transactions are properly recorded. If the risk of evasion is regarded to be low, an authorization is issued that allows for simplified procedures e.g. a monitoring of trade flows and stocks based on post-transaction audits. In this case, single transactions of companies are ascertained which includes a verification of documentation. ${ }^{96}$

This approach should also be adopted under the IoC. Companies would have to prove that sufficient accounting and recording systems are in place and that transactions are documented precisely. Instead of verifying the liabilities created, transferred, held and acquitted based on physical audits, liabilities would then be monitored by relying on transactions conducted and the records provided. As liabilities are calculated according to weight of carbon intensive material, it would be sufficient that documents and records state the weight of carbon intensive material instead of a monetary value.

\section{Required information and verification}

Under the transaction-based approach for monitoring, the chargeable persons would need to report certain information that then can be verified by state officials. The information, its documentation and verification would concern the creation of liability upon production, the

\footnotetext{
${ }^{95}$ On customs procedures see A. Goormann, 'Duty relief and exemption control' in L. De Wulf and J. B. Sokol (eds), Customs Modernization Handbook (The World Bank 2005), 215, at p 231; S. Samen, 'Policy Practices and Institutions for Successful Export Development and Diversification in Developing Countries' in A. Lukauskas, M. Stern and G. Zanini (eds), Handbook of trade Policy for Development (Oxford University Press 2013), 444, at p 452. On excise see E. Sunley et al., 'The design, administration and potential revenue of tobacco taxes' in P. Jha and F.J. Chaloupka (eds), Tobacco control in developing countries (Oxford University Press 2000), 409, chapter 17.3.4 on physical controls; World Health Organization, WHO technical manual on tobacco tax administration (World Health Organization 2011), at chapter 3.1.3 on ensure tax compliance for higher revenues and chapter 3.1.4 on monitoring production.

${ }^{96}$ A. Goormann, n. 95 above, at p 231; S. Samen, n. 95 above, at p 452; Customs and Excise Department Hong Kong, 'Open Bond System to Facilitate Trade' (Customs and Excise Department Hong Kong) < http://www.customs.gov.hk/filemanager/common/pdf/pdf_publications/pamphlet/open_bond_eng.pdf> accessed 1 May 2016. On this see also D. Widdowson, 'Managing Risk in the Customs Context' in L. De Wulf and J. B. Sokol (eds), Customs Modernization Handbook (The World Bank 2005), 91.
} 
movement of carbon intensive material under duty suspension, the release for consumption as well as the creation and acquittal of liability upon import and export.

\section{a) Creation of liability upon production}

Producers of carbon intensive materials subject to the IoC would have to account for the weight of primary product. In the steel sector this would comprise e.g. the weight of steel per unit of hot rolled coil. The production volumes would then be reported to governments on a quarterly basis.

At first glance, the verification of production data would appear problematic as the documentation heavily relies on the producer. However, it has to be seen that there is a counter-balancing influence: the reported production data would also be used for the determination of the free allowance allocation. ${ }^{97}$ Any under-reporting of production data would translate into a decreased free allocation. Hence, production volumes reported to governments could be subject to somewhat less stringent verification procedures.

\section{b) Movement of carbon intensive material under duty suspension}

When moving carbon intensive materials under duty suspension, authorized persons would have to account and report on the trade flows of ingoing or outgoing carbon intensive materials. This would in particular encompass the weight of such materials. Furthermore, the reporting would also extend to the corresponding liabilities transferred respectively assumed.

The trade flows and liabilities would then have to be verified by governments. The monitoring and verification of movements under the IoC should not follow the model implemented for high tax goods such as alcohol under excise duties, which are subject to stringent and permanent controls under the Excise Movement and Control System (EMCS). ${ }^{98}$ Instead, a simplified version would suffice given the relatively low amount of the charge. ${ }^{99}$ The movement of carbon intensive materials and the transfer of liabilities would thus be proven by commercial documents that are already required for VAT purposes e.g. invoice statements. ${ }^{100}$ The documentation, however, would have to be extended by the weight of carbon intensive material transferred.

Verification of the transfer of liabilities between two authorized persons would pose less of a problem, as there would be a conflict of interest between two independent economic actors. ${ }^{101}$ While the consignor would tend to over-state the liability transferred, the consignee

\footnotetext{
${ }^{97}$ Cf. B. Borkent et al., n. 25 above, at p 24.

${ }^{98}$ Commission Regulation (EC) no 684/2009 of 24 July 2009 implementing Council Directive 2008/118/EC as regards the computerised procedures for the movement of excise goods under suspension of excise duty [2009] OJ L 197, 24. A description of the EMCS is provided by Commission, 'EMCS: How it works' < http://ec.europa.eu/taxation_customs/taxation/excise_duties/circulation_control/how_it_works/index_en.htm> accessed 1 May 2016. See also H. Jatzke, n. 60 above, at pp 5 et seq.

${ }^{99}$ A calculation of the charge per ton of basic material as well as relative price changes are provided by S. Pauliuk et al., Quantifying Impacts of Consumption Based Charge for Carbon Intensive Materials on Products (DIW Discussion Paper 1570, DIW 2016), at pp 8 et seqq and pp 21 et seqq.

${ }^{100}$ See Article 220 of the Council Directive 2006/112/EC of 28 November 2006 on the common system of value added tax [2006] OJ L 347, 1.

${ }^{101}$ Similar aspects can be found in the debate about Transfer Pricing, cf. OCED, OECD Transfer Pricing Guidelines for Multinational Enterprises and Tax Administrations (OECD Publishing 2010), at pp 31 et seqq.
} 
in contrast would aim to receive as little liability as possible. This conflict of interest would help to ensure the correct transfer of liability.

Nevertheless, the problem might occur that either the receipt of liability is not recorded by the consignee at all or, that the transfer is recorded, but the data recorded by the consignor and the consignee do not correspond. This problem could be solved by first adding the identification number issued upon authorization on the document of proof, and second by requiring a letter of acceptance of liability by the consignee. Therefore, it would be sufficient when the consignee returned electronically a signed copy of the invoice that statedthe amount of liability transferred to the consignor. Governments could then audit selected transactions. Where no letter of acceptance existed, the transfer of liability would be deemed to not have taken place.

For reasons of cost efficiency, a summarized letter of acceptance could be issued for all transactions that took part within a certain period, for example on a quarterly basis. ${ }^{102}$ Where close trade relations exist between two authorized persons, it is also conceivable that no letter of acceptance would be issued at all. Rather trade partners could agree on a kind of debt assumption where the transfer of liability was automatically accepted by the consignee for all transaction conducted.

\section{c) Release for consumption}

Upon release for consumption, the authorized persons would have to account for and report on the weight of carbon intensive material released for consumption, as well as on the amount of charge collected. This information would have to be added to the invoice.

\section{d) Creation and acquittal of liability upon import and export}

Upon importation and exportation, authorized persons would have to report on the corresponding weight of carbon intensive materials. This information would form part of the customs declaration documentation.

Verification of the weight of basic material or bulk products would be fairly straightforward, as the total weight of the imported product is already stated on the customs declaration and the weight of carbon intensive material could be derived from this information. For intermediary and final products, the information provided by producers could be verified with reference to product category-specific material benchmarks reflecting the average carbon intensive materials content of a product category. ${ }^{103}$ Deviations between

\footnotetext{
${ }^{102}$ In the EU, such simplification is also possible under Article 31 of the Excise Directive and have to be established by bilateral agreements between Member States. Simplifications apply in the following countries: Austria, Czech Republic, Germany, France, Italy, Lithuania, Netherlands, Romania, Slovakia (Committee on Excise Duties, Use by the Member Stated of the optional provisions of Chapter IV of Directive 2008/118/EC concerning the movement of excise goods under suspension of excise duty and of the optional data in Annex I of its Implementation Regulation (EC) 684/2009 (TAXUD/308259/2009, European Commission 2012), at pp 16 et seqq.

${ }^{103}$ Cf. C. McAusland and N. Najjar, n. 27 above, at pp 770 et seq.
} 
the base of assessment stated on the invoice and the average liability of a product could lead to more intensive verification. ${ }^{104}$

\section{E. Conclusion}

Carbon pricing is necessary for facilitating a deep decarbonisation of the whole economy. Yet international carbon prices are expected to vary across regions in the long term. Concerns about carbon leakage persist. Both under unmitigated carbon leakage and under free allocation of allowances, the carbon price signal is muted along the value chain and incentives for innovation, substitution and material efficiencies are lost. In the literature, most attention has so far been devoted to Border Carbon Adjustments (BCA) as an alternative approach which promises to restore full incentives of mitigation. Recently, however, the Inclusion of Consumption into the EU ETS, which combines a charge on the consumption of carbon intensive commodities with free allocation based on actual or recent production volumes, has become a subject of a rapidly developing literature.

This article has explored the precise legal design of such a charge in the context of emissions trading schemes as well as the most important administrative aspects. The IoC is not a fundamental alternative to such schemes, but a complement, which fixes some of its deficits. While the paper has used the example of the EU ETS for purposes of illustration, the general results can be transferred to other emissions trading schemes:

1. In a purely domestic context, the widest possible scope of the IoC would be determined by the sectors deemed to be at risk of carbon leakage and thus profiting from free allocation. ${ }^{105}$ The calculation of the payable amount under the charge would depend on the base of assessment and on the applicable rate. The former would follow product-specific benchmarks which are already used for free allocation of allowances, whereas the latter would be governed by the preceding year`s average market price of allowances. ${ }^{106}$ The chargeable moment would be determined in line with excise duties: while the liability would already be created when the basic material in question such as steel has been produced, it would become due only once the good is released for consumption. The corresponding technical fix - the above-mentioned duty suspension arrangements - would reduce the potential for fraud. The use of revenue would mirror general choices made in the EU ETS at large. ${ }^{107}$

2. In the international context, the charge should be implemented in accordance with the destination principle. Exports would be relieved automatically where the exported good had been held under duty suspension arrangements. ${ }^{108}$ By contrast, imports would give rise to the liability to the charge, which would be calculated according to the materials content, the emissions benchmark and the applicable rate. As for the case of production, imported goods

\footnotetext{
${ }^{104}$ Where such information was considered not sufficiently reliable and random testing of the composition of the imported goods was deemed impractical, product category-specific material benchmarks could be applied that determine the amount of liability created upon import in line with the average liability associated with a product category. Similar procedures should apply to exports.

105 See above at B.I.

106 See above at B.II.

${ }^{107}$ See above at B.III.

108 See above at C.I.
} 
could also be held under a duty suspension arrangement. The charge should not be limited to the importation of basic materials, but also extend to the importation of intermediary and final products where the share of carbon costs linked to basic materials contained in the product relative to the product value exceeds a certain threshold level. ${ }^{109}$

3. The administration of the scheme should be designed in a way that ensures a sufficient level of compliance at minimal administrative and compliance costs. For that purpose, the established role model of excise should be followed. In particular, duty suspension arrangements would create the need for determining who qualifies for participation in such arrangements. Monitoring of liabilities should follow a transaction-based approach. This would require the chargeable persons to report certain information regarding the creation of liability upon production, the movement of carbon intensive material under duty suspension, and the release for consumption and the creation and acquittal of liability upon importation and exportation. ${ }^{110}$

The combination of dynamic free allocation and the IoC is thus ripe for implementation. It represents a legally and politically feasible instrument, which allows both to address leakage concerns and to send a carbon price signal down the value chain. In particular, the IoC complies with the obligations under WTO law and can be in Europe be implemented as environmental regulation as part of EU ETS. The scheme will also work in practice, when it follows procedures long established under excise and customs: The scheme can be expected to work in a reliable manner and to be resilient to attempts of fraud. At the same time, administration and compliance costs will be reasonable.

In a similar vein, the approach may be applied mutatis mutandis to other forms of carbon pricing. For a carbon tax, there would be a partial upstream tax exemption for carbon emissions at the benchmark level. The partial exemption would correspond to free allocation under emissions trading schemes. ${ }^{111}$ It would be combined with an excise on basic materials which would share the main traits of the charge under the IoC; notable exceptions would include the connections to the carbon price and the use revenue. Applying the approach to a Carbon tax would promise similar benefits as for emissions trading schemes. In particular, the individual carbon emissions from the production a particular good would not have to established upon importation or exportation; instead, it would suffice to find out how much of carbon intensive basic materials is contained in the good at hand. All this suggests that for different types of Carbon pricing the IoC can make a valuable contribution to setting the right incentives for decarbonisation in the materials sectors in a world of unequal carbon prices.

\footnotetext{
${ }^{109}$ See above at C.II.

${ }^{110}$ See above at D.

${ }^{111}$ For an example see e.g. Sec. 9, 9a of the German Electricity Tax Act which grant partial exemptions for energy intensive industry. The exemptions serve a function similar to free allocation under emissions trading systems.
} 